\title{
Spatio-temporal assessment of rice self-sufficiency in West Sulawesi Province, Indonesia
}

\author{
Heein Yang ${ }^{1}$, Amanda Rastiana Putri ${ }^{2}$, Ali Muta'aly Muhammad ${ }^{2}$, Alim Rohman ${ }^{2}$, Hanifah Nur Fadhilah ${ }^{2}$, Ihsan Weda \\ Prabaswara $^{2}$, Thalia Mutiara Fikri², and Ratih Fitria Putri2* \\ ${ }^{1}$ Departement of Electrical and Computer Engineering, Ajou University, Korea \\ ${ }^{2}$ Environmental Geography, Department of Environmental Geography, Faculty of Geography, Universitas Gadjah Mada, Indonesia
}

\begin{abstract}
Agriculture is an important economic sector in human life. One of the analyses of agricultural resources is food adequacy which is closely related to food availability and food needs. The research location of this study is West Sulawesi Province which has the potential for economic development to improve the welfare of its people and be able to implement sustainable development. The purpose of this study is to determine rice sufficiency from 2016 to 2020 for each district and to projected it for several years. The research was conducted by quantitative methods and analyzed descriptively and spatially. The data collection method is documentation method by literature studies to collect secondary data from Central Statistics Bureau (BPS) of West Sulawesi Province. In general, rice sufficiency in West Sulawesi Province from 2016 to 2020 is included in the sufficient category. However, for several years there were two districts with inadequate amounts of rice, which were Majene and North Mamuju. The projection results in 2025 and 2030 also show the same thing, Majene and North Mamuju are still in the insufficient category and it will get worse in 2030. So in general, West Sulawesi Province is predicted to be unable to meet food needs.
\end{abstract}

\section{Introduction}

Food is one of the basic needs and includes human rights that play an important role in maintaining the life and livelihood of human beings [1]. Based on Law Number 18 of 2012 [2] concerning food, it is explained that food is a mandatory responsibility for the state in realizing the availability, affordability, and fulfillment of sufficient, safe, quality, and nutritionally balanced food consumption, both at the national and individual levels. evenly throughout the region. Food has a role in realizing quality human resources in order to carry out daily life. Food consumption patterns have changed from time to time caused by changes in household income, public awareness of food and nutrition and community behavior [3]. Therefore, it is important to meet food needs through its availability. Availability of food that is lower than the need, can create national food instability [4]. In addition, food also occupies a high priority in economic development, because the failure of food production can cause price spikes and scarcity in the market which has an impact on socio-political turmoil [5].

West Sulawesi Province is the last province to be established on the island of Sulawesi. The province was established in 2004 as part of decentralization in Indonesia. West Sulawesi Province consists of six regencies, namely Majene Regency, Polewali Mandar Regency, Mamasa Regency, Mamuju Regency, North Mamuju Regency (Pasangkayu), and Central Mamuju Regency which are the result of division in 2014. Food consumption among districts in West Sulawesi Province can vary depending on the environment including local resources and culture, tastes, and income of the community [6]. Sufficient food in an area is necessary to meet the needs and assist regional development. Therefore, as a newly formed region, West Sulawesi must maintain its sustainability, including its food resources, to further develop the region.

A person's survival is related to food sufficiency since food is an important source of nutrition for the human body to achieve prosperity and improve individual health. Fulfillment of food sufficiency is essential to improve human resource quality by providing a sufficient amount of nutritious, safe, and affordable food for everyone in the respective region [6]. Sufficient food in an area can be used as an indicator of the fulfillment of public consumption. A region with enough food sufficiency will provide better public prosperity compared to a region without sufficient amount of food [7]. Thus, adequate amounts of food are essential for the survival and development of a community.

Food sufficiency is one of the determinants of economic stability. Thus, food self-sufficiency becomes a development framework that can encourage the development of other sectors in the region [8]. According to BPS [9] (2015), the agricultural sector is still the dominant sector in the economic structure in West Sulawesi. The agricultural sector has a contribution of $39.71 \%$ to the Gross Domestic Product (GDP) in West

\footnotetext{
* Corresponding author : ratihfitria.putri@ugm.ac.id
} 
Sulawesi. Absorption of labor in the agricultural sector in West Sulawesi in 2020 was around 337,770 people, an increase compared to the previous year which reached 297,366 people [10]. In general, food sufficiency aims to achieve food availability, price stability, as well as affordability for the community [11]. One of the government's efforts in realizing food sufficiency is carried out through Government Regulation (PP) number 68 year 2002 [12] concerning food sufficiency which states that the provision of food is carried out to meet the needs of household food consumption which continues to grow from time to time.

Rice as a strategic food commodity needs to be guaranteed its availability to meet the food needs of the community. Decrease in agricultural land area in agricultural activities will have an impact on food sufficiency. This is because the availability of rice can affect economic conditions, especially as rice is still the main food commodity [13].

The second goal of the SDGs is to eliminate, achieve food sufficiency and good nutrition, and promote sustainable agriculture. Sustainable agriculture is the management of agricultural resources carried out to meet the needs of present and future generations, by caring for and improving the quality of the environment and preserving natural resources [14]. One of the indicators in achieving sustainable agriculture is the proportion of productive and sustainable agricultural areas [15] [16].

The main problem in fulfilling food self-sufficiency in an area is the change in land use and a decrease in agricultural productivity [17]. The area of agricultural land is one of the important factors that affect food availability, where currently the area is fixed and even tends to decrease [18]. A decrease in the area of agricultural land is always associated with an increase in population due to the economic development of a region [19]. West Sulawesi Province experienced a population growth of $8.63 \%$ in 2016 to 2020 or an increase of around 112,751 people over the last 5 years. The increase in population demands the conversion of agricultural land to other land uses. From 2015 to 2019, agricultural land, especially rice fields, has decreased by around 2353 hectares. As a result, rice production in West Sulawesi Province from 2016 to 2020 tends to decrease [10]. The increase in population should be balanced with increasing rice production, but in fact the ability to supply rice is increasingly limited. With these conditions, it is feared that food self-sufficiency, especially rice in the future, will not be achieved if the amount of availability continues to decline and is not higher than the need for rice [20].

The study was conducted to determine rice selfsufficiency in West Sulawesi in 2016-2020 and the results of the calculation can be used to represent the condition of agricultural resources and determine appropriate agricultural policies. Furthermore, this study also aims to estimate the rice self-sufficiency of West Sulawesi Province in 2025 and 2030.

\section{Methods}

\subsection{Study area}

West Sulawesi Province has an area of 16.937,16 square kilometers. The northern part is bordered by Central Sulawesi Province, the southern part is bordered by South Sulawesi Province and Mandar Bay, bordered by Central Sulawesi Province and South Sulawesi Province in the east and Makassar Strait in the west. The map of West Sulawesi Province can be seen in Figure 1.

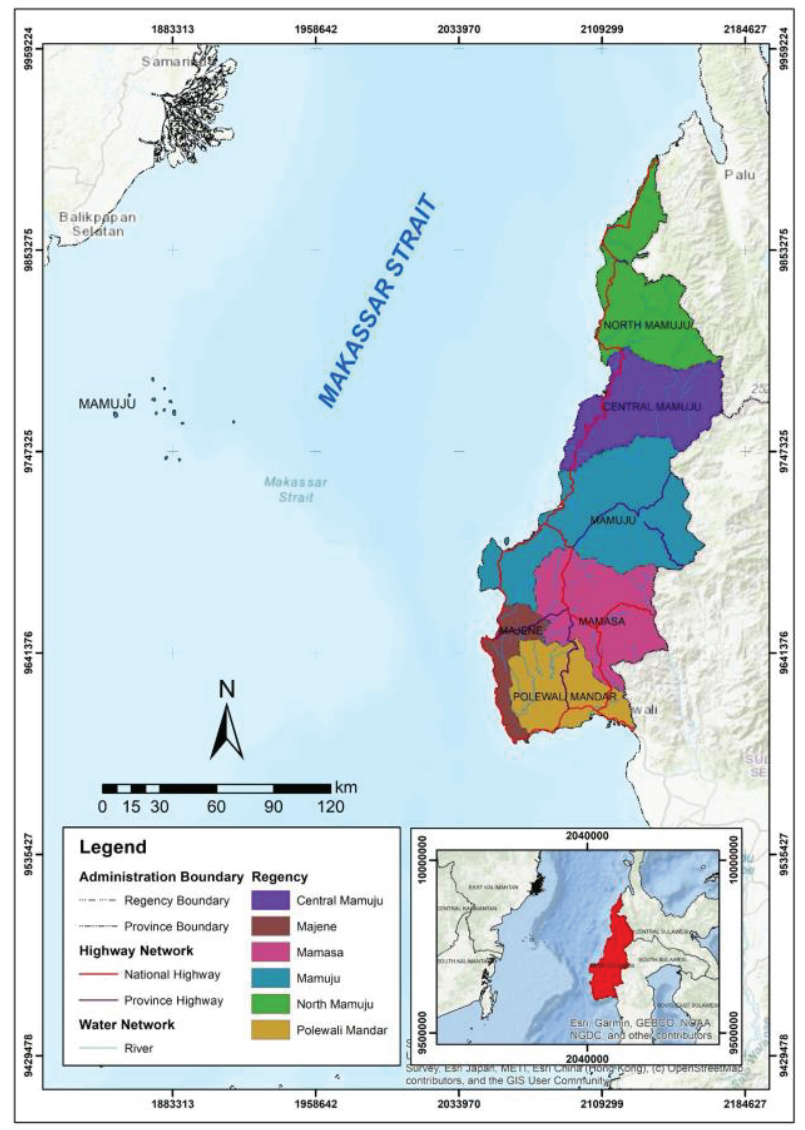

Fig. 1. West Sulawesi map

West Sulawesi Province consists of six regencies, namely Majene Regency, Polewali Mandar Regency, Mamasa Regency, Mamuju Regency, North Mamuju Regency (Pasangkayu), and Central Mamuju Regency which are the result of regional expansion in 2014. West Sulawesi was chosen as the study location because food crops are one of the dominant agricultural sub-sectors with $46.35 \%$ of the population working in the agricultural sector [21]. One of the priorities of the West Sulawesi government program is to increase food security to support the availability of staple food for the population [22]. Potential agricultural land area of 1,429.29 square kilometers, community cultural factors and supportive agro-climatic conditions make West Sulawesi potential to become one of the national food barns in Eastern Indonesia. 


\subsection{Population and sample}

The research was conducted by quantitative methods and analyzed descriptively and spatially. Quantitative method is used to calculate the rice sufficiency value in West Sulawesi 2016-2020. The population in this study is the Province of West Sulawesi. The sample in this study was 6 regencies in West Sulawesi, namely Majene, Polewali Mandar, Mamasa, Mamuju, North Mamuju, and Central Mamuju.

The data collection method was a documentation method by literature studies to collect secondary data from BPS of West Sulawesi Province including the publication of West Sulawesi Province in Figures for 2017-2021 and the publication of the Study of Consumption of Staples in 2017 by BPS which was accessed online. Administrative boundaries data of West Sulawesi Province collected from Badan Informasi Geospasial $(B I G)$, downloaded through the Ina-geoportal website.

\subsection{Rice sufficiency value}

The concept of rice sufficiency is a comparison between availability and needs. The rice sufficiency value is calculated using the variables annual rice production, population per year, and annual rice consumption per capita. Rice sufficiency value is calculated using Equation (1).

$$
S=\frac{P}{(n \times C) / 1000}
$$

where, $S$ is rice sufficiency value, $P$ is annual rice production ( $\mathrm{kg} / \mathrm{ha} / \mathrm{year}), n$ is population of West Sulawesi Province (People/year), and $C$ is annual rice consumption per capita ( $\mathrm{kg} /$ year). The calculated $S$ with value above 1 means the rice supply is sufficient, while the value below 1 means rice supply is insufficient.

\subsection{Projection of rice sufficiency value}

The projection of rice sufficiency in 2025 and 2030 takes into account the value of availability and needs of rice. This research uses the assumption that every population has the same value of rice consumption needs. Projection of rice sufficiency value is calculated using Equation (2).

$$
P n=P o(1+r)^{n}
$$

where, $P n$ is projection of rice sufficiency value, $P o$ is annual rice production at year $0(\mathrm{~kg} / \mathrm{ha} /$ year $), n$ is the number of years between 0 to $\mathrm{n}$, and $r$ is average availability of rice in $n$.

Data analysis is based on the results of calculations and spatial data on rice sufficiency of West Sulawesi Province from 2016 to 2020. Tabular data including rice production data, population data, and rice consumption per capita were processed utilizing Microsoft Office Excel software. The presentation of data calculation results of rice sufficiency using tables and diagrams while rice sufficiency maps were made using ArcMap 10.5.

\section{Results and discussion}

\subsection{Rice sufficiency value of West Sulawesi Province}

Rice production from 2016 to 2020 tends to decrease. Rice production in 2016 reached 548,536 tons, increased in 2017 to 667,097 tons. There was a significant decrease in rice production in 2018 and 2019 as much as 326,196 tons and 300,142 tons, respectively. Meanwhile, in 2020 there was an increase in rice production of 319,166 tons. The number of residents in West Sulawesi Province from 2016 to 2020 continues to increase as the region develops. There were $1,306,480$ people in 2016, 1,330,960 people in $2017,1,355,550$ people in $2018,1,380,260$ people in 2019 , and $1,419,230$ people in 2020 . The growth of population from 2016 to 2020 affects the food sufficiency in West Sulawesi as the growth of food demand forms a relatively similar pattern as population growth. Annual estimation of rice consumption per capita in West Sulawesi Province from 2016 to 2020 is $126.4 \mathrm{~kg}$.

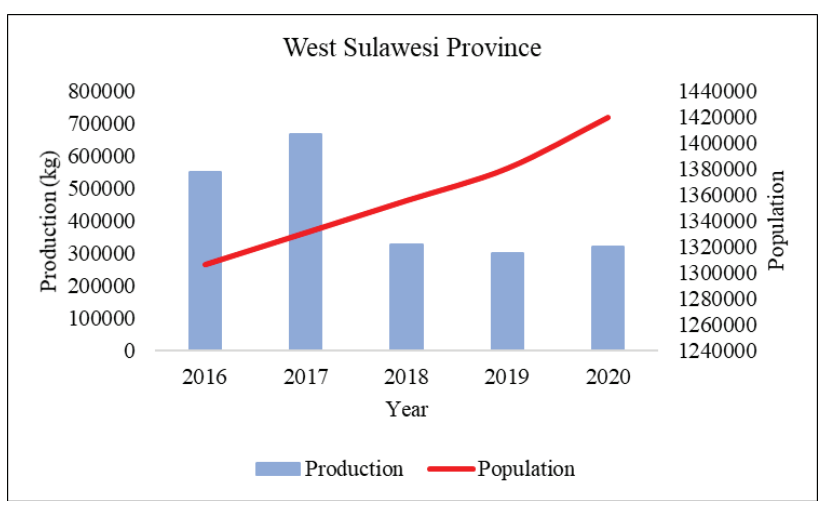

Fig. 2. Comparison of rice production and population in West Sulawesi Province 2016-2020

Based on the amount of rice production, population, and consumption per capita, it can be determined the value of rice sufficiency from 2016 to 2020. Based on the calculation results, it can be seen that the rice commodity from 2016 to 2020 is classified as sufficient with a value greater than 1. Although it is said to be sufficient, the value of the sufficiency of rice commodities in West Sulawesi tends to decline, especially in 2018. This happens because rice production has decreased while the population has increased so that the sufficiency of rice in 2018 has decreased. The land conversion of paddy fields to non paddy fields caused the reduction of rice production. The area of paddy fields and harvested land can affect the availability of rice, the larger the area of harvested land, the greater the production of rice produced [16]. Based on data in 2010-2019, the land use with the narrowest area is paddy fields. Changes in the area of paddy fields tend to fluctuate or have experienced increases and decreases in the area in certain years. In 2010-2014 there was a decrease in the area of around 1200 ha, while in 2015-2019 it was around 2000 ha. 
Table 1. Rice sufficiency value in each district

\begin{tabular}{|c|c|c|c|c|c|}
\hline \multirow{2}{*}{ District } & \multicolumn{5}{|c|}{ Rice sufficiency value } \\
\cline { 2 - 6 } & $\mathbf{2 0 1 6}$ & $\mathbf{2 0 1 7}$ & $\mathbf{2 0 1 8}$ & $\mathbf{2 0 1 9}$ & $\mathbf{2 0 2 0}$ \\
\hline Majene & 0.74 & 1.00 & 0.19 & 0.19 & 0.17 \\
\hline $\begin{array}{c}\text { Polewali } \\
\text { Mandar }\end{array}$ & 4.09 & 4.57 & 3.27 & 3.00 & 2.89 \\
\hline Mamasa & 4.46 & 5.64 & 3.55 & 2.74 & 2.73 \\
\hline Mamuju & 4.14 & 4.22 & 1.22 & 1.34 & 1.74 \\
\hline $\begin{array}{c}\text { North } \\
\text { Mamuju }\end{array}$ & 1.38 & 1.82 & 0.40 & 0.10 & 0.12 \\
\hline $\begin{array}{c}\text { Central } \\
\text { Mamuju }\end{array}$ & 3.43 & 6.03 & 1.04 & 1.19 & 1.20 \\
\hline $\begin{array}{c}\text { West } \\
\text { Sulawesi } \\
\text { Province }\end{array}$ & 3.32 & 3.97 & 1.90 & 1.72 & 1.78 \\
\hline
\end{tabular}

Source: Data processing (2021)

The sufficiency of rice commodities by district from 2016 to 2020 tends to be sufficient, although several districts tend to be insufficient, namely Majene Regency and North Mamuju Regency. Food sufficiency for rice commodities in Majene Regency in 2016, 2018, 2019, and 2020 was not sufficient, but in 2017 it was sufficient. The rice commodity in Majene Regency which is not fulfilled is dominated by a significant decrease in rice production while the population continues to increase.

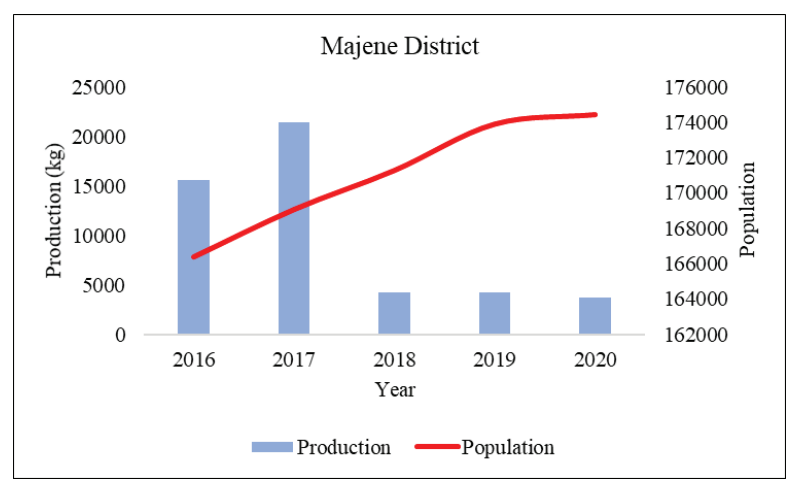

Fig. 3. Comparison of rice production and population in Majene District 2016-2020

The magnitude of the decline in rice production from 2017 to 2018 was 17,178 tons, where the decline was quite large. Food sufficiency in 2017 was considered sufficient because rice production in 2017 increased by 5,765 tons even though the population also increased. North Mamuju Regency tends not to have its food needs fulfilled, only in North Mamuju Regency in 2016 and 2017 the food needs of rice commodities are fulfilled while in 2018, 2019, and 2020 it is not fulfilled. This is because there was a significant decrease in production in 2018 which was 29,484 tons of rice, in 2019 there was a decrease in the production of 6,333 tons of rice, while in 2020 there was an increase in production of 594 tons of rice. Changes in the amount of rice production are accompanied by an increase in population so that when rice production decreases while the population increases, the sufficiency of food commodities can not be fulfilled.

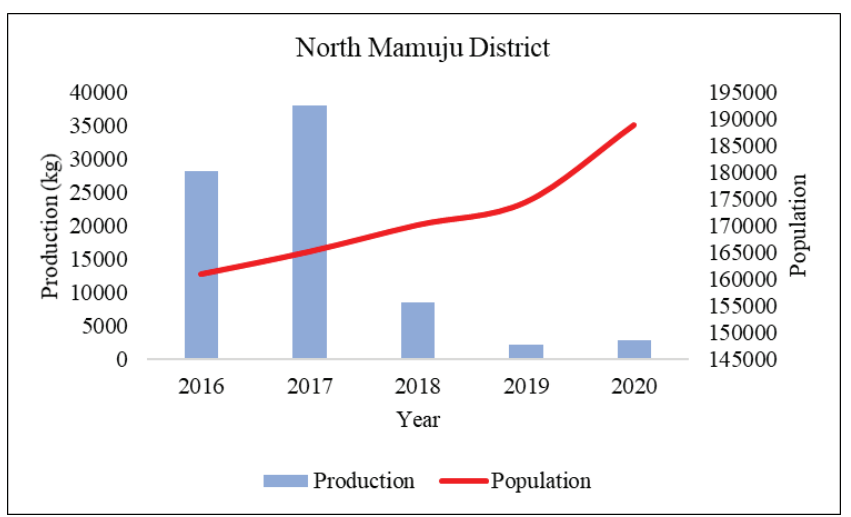

Fig. 4. Comparison of rice production and population in North Mamuju District 2016-2020

\subsection{Trend of rice sufficiency value}

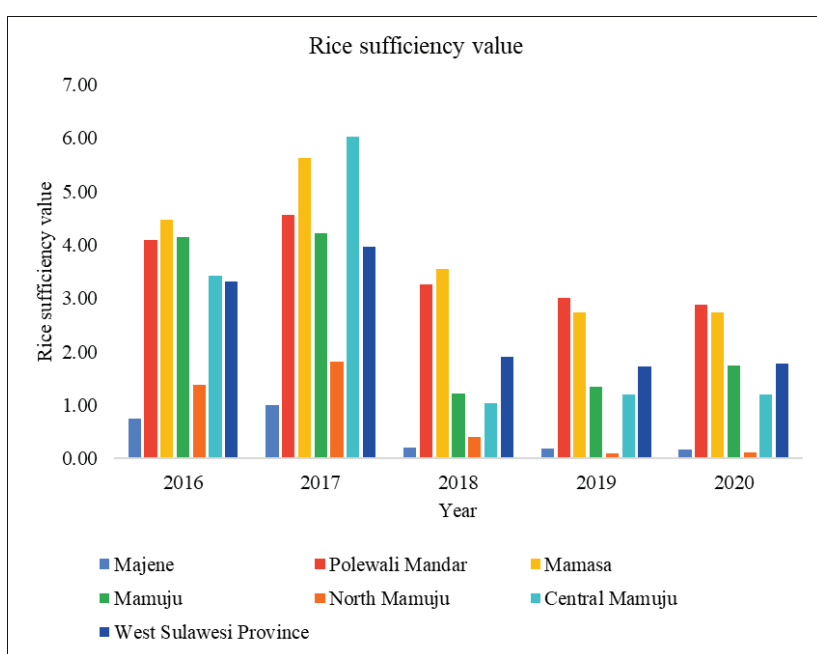

Fig. 5. Trend of rice sufficiency value in West Sulawesi Province 2016-2020

Rice commodities in Polewali Mandar Regency, Mamasa Regency, Mamuju Regency, and Central Mamuju Regency from 2016 to 2020 are sufficient. Although it is said to be sufficient, the value of the sufficiency of rice commodities in West Sulawesi tends to decrease, especially in 2018. This is because rice production has decreased significantly while the population has increased so that rice sufficiency in 2018 has decreased. Polewali Mandar Regency rice production tends to decrease although in 2017 it increased, in 2018 and 2019 it decreased, while it increased again in 2020. The amount of rice production in Polewali Mandar Regency is still quite sufficient to meet the food needs of the population. Likewise in Mamasa Regency and Mamuju Regency, which experienced a decrease in production in 2018 and 2019 and then increased in 2020 with a population that continues to increase, but can still meet the food sufficiency of the population. Central Mamuju Regency rice production increased from 2016 to 2017 and in 2018 decreased, but rice production increased again in 2019 and 2020 so that food availability was still sufficient for the population. 
Based on the food sufficiency map of West Sulawesi Province in 2016 and 2020, it can be seen that there is a change in food sufficiency from 2016 to 2020 . However, this change leads to inequality in food sufficiency in West Sulawesi Province. This is indicated by food sufficiency which is almost evenly distributed in all districts in 2016 where only Majene District has insufficient food sufficiency. Meanwhile, in 2020 there was a change in food sufficiency where there was one district that initially had sufficient food sufficiency to become insufficient, namely North Mamuju Regency. This inequality in food sufficiency is due to the decline in rice production while the population is increasing so that food sufficiency tends to decrease.

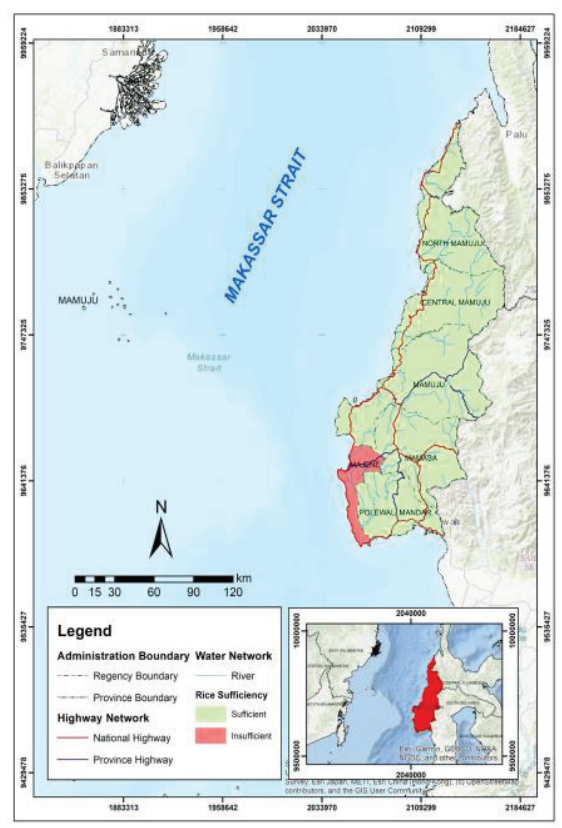

Fig. 6. Spatial distribution of rice sufficiency value in West Sulawesi Province in 2016

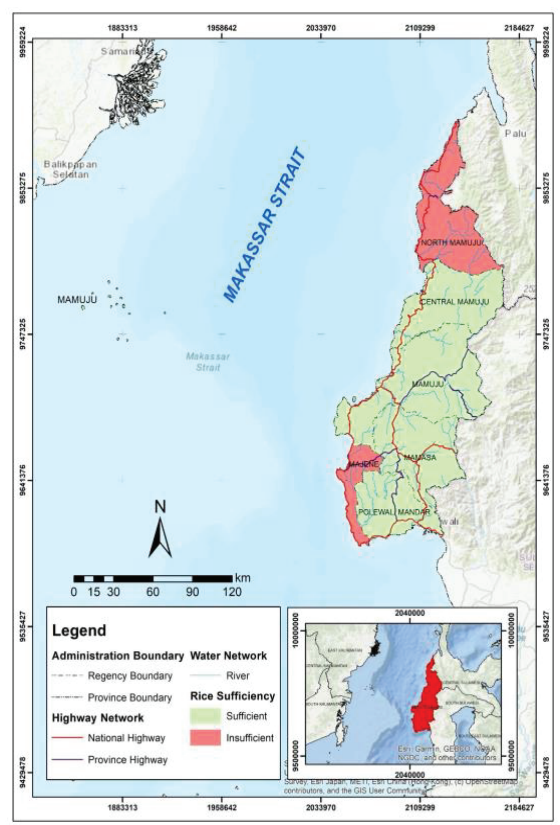

Fig. 7. Spatial Distribution of rice sufficiency value in West Sulawesi Province in 2020
One of the goals of the SDGs is to achieve sustainable agriculture. However, based on the results of the calculation of food sufficiency between 2016 and 2020, it shows that there is a shortage of main food sources. If in 2016 there was only 1 district experiencing shortages, in 2020 there will be 2 districts. This shows that the Province of West Sulawesi does not yet have a sustainable agricultural system.

\subsection{Projection of rice sufficiency value in 2025 and 2030}

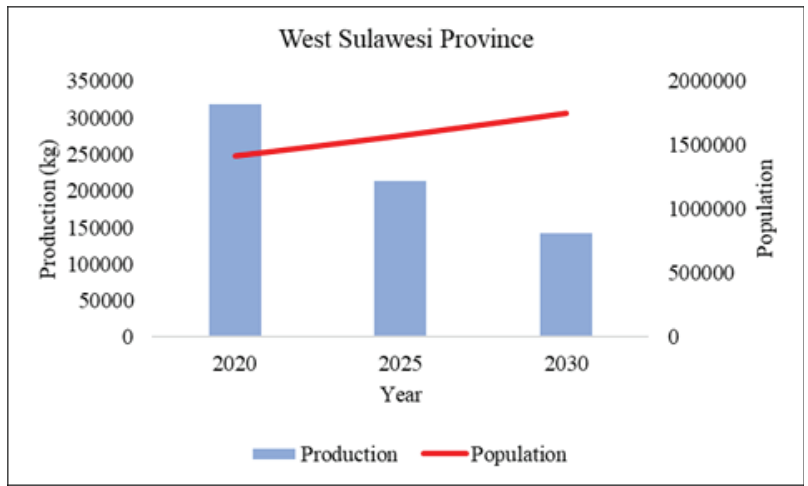

Fig 8. Comparison of rice production and population in West Sulawesi Province 2020, 2025, and 2030

The results of the projection of rice production in West Sulawesi in 2020, 2025, 2030 show that the amount of rice production is decreasing but the population is increasing. The increase in population resulted in the conversion of agricultural land into non-agricultural land. Population increase has a positive effect on land conversion [23]. Conversion of land that continues to occur will then have an impact on rice production. If there are no policies implemented, the results of rice production cannot meet the needs of the population. This can be a challenge for the future [13].

Table 2. Rice sufficiency value in each district

\begin{tabular}{|c|c|c|}
\hline \multirow{2}{*}{ District } & \multicolumn{2}{|c|}{ Rice Sufficiency Value } \\
\cline { 2 - 3 } & $\mathbf{2 0 2 5}$ & $\mathbf{2 0 3 0}$ \\
\hline Majene & 0.07 & 0.03 \\
\hline $\begin{array}{c}\text { Polewali } \\
\text { Mandar }\end{array}$ & 1.99 & 1.38 \\
\hline Mamasa & 1.75 & 1.13 \\
\hline Mamuju & 1.14 & 0.74 \\
\hline $\begin{array}{c}\text { North } \\
\text { Mamuju }\end{array}$ & 0.03 & 0.01 \\
\hline $\begin{array}{c}\text { Central } \\
\text { Mamuju }\end{array}$ & 1.33 & 1.48 \\
\hline $\begin{array}{c}\text { West } \\
\text { Sulawesi } \\
\text { Province }\end{array}$ & 1.07 & 0.64 \\
\hline
\end{tabular}

Source: Data processing (2021) 


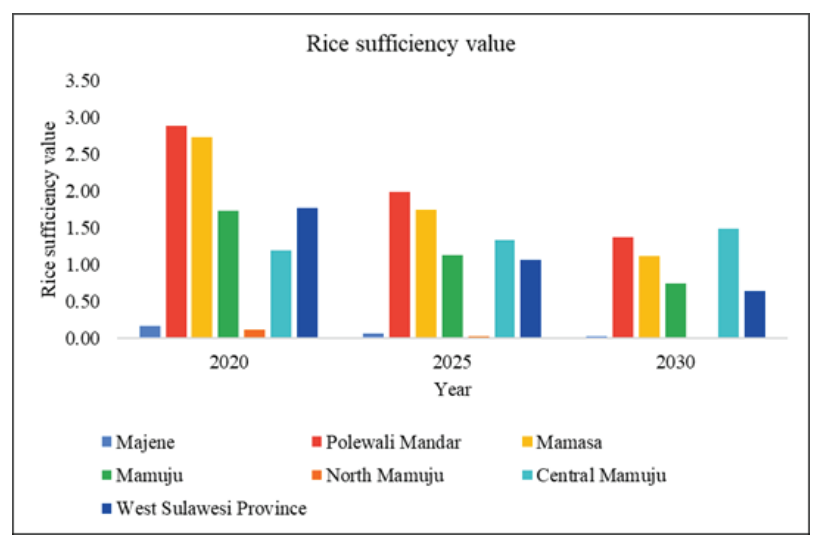

Fig. 9. Trend of rice sufficiency value in West Sulawesi Province 2020-2030

The results of the calculation of food adequacy in West Sulawesi in 2025 and 2030 for each district/city have varying values (Table 2). There are regencies/cities that can still have enough food and cannot have enough food. Districts projected in 2025 to be able to meet their food requirements then in 2030 cannot be sufficient, namely Mamuju Regency, while districts projected in 2025 and 2030 cannot be sufficient for food, namely Majene Regency and North Mamuju Regency. What is quite interesting from the results of the calculation of the projection of each district is that almost all districts have insufficient values for 2030, in contrast to Central Mamuju Regency which actually experienced an increase in the value of food sufficiency in the next five years projection period.

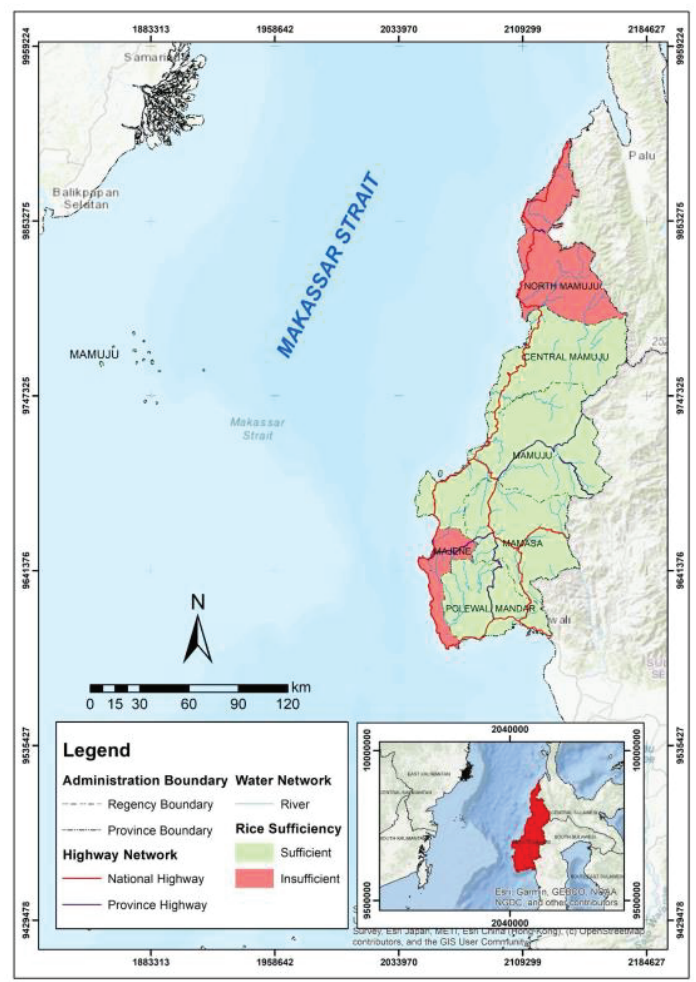

Fig. 10. Spatial distribution of rice sufficiency value in West Sulawesi Province in 2025

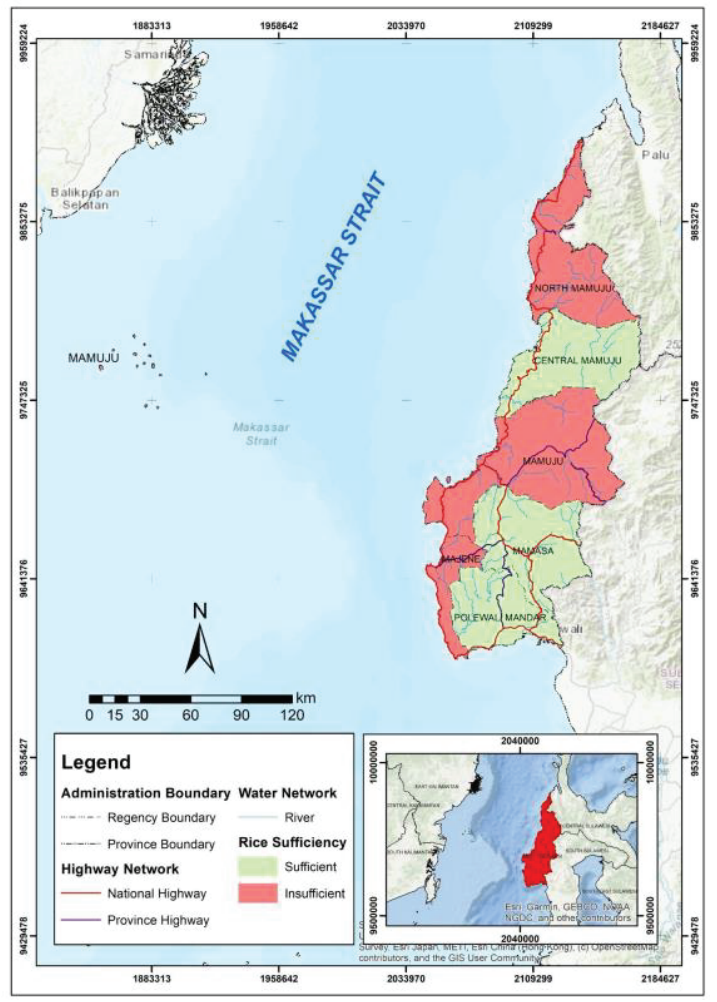

Fig. 11. Spatial distribution of rice sufficiency value in West Sulawesi Province in 2030

In general, it can be seen on the map over the next five years, namely in 2030 there will be an addition to three districts that fall into the insufficient category as shown in (Fig. 11). This will continue to happen over time if no preventive steps are taken from the government or related agencies to prevent it. One solution to deal with insufficient food needs is through the use of technology. The existence of rapid technological developments can offer a good solution to address the problem of sustainable food needs in the future [24]. Those who ignore global food projections and scenarios in the future tend to view this problem as a supply problem and do not focus on increasing food production through technology [25]. Based on this statement, it would be better if the parties responsible for handling the problem of food needs in West Sulawesi Province should not ignore the prediction of the condition of food needs in the future.

\section{Conclusion}

The necessity of food sufficiency must be considered by every stakeholder including government, public institutions like non-governmental organizations (NGO), and the community itself. The increase in food production is related to the physical, social, economic, and environmental aspects, while food demand is in line with the increasing population, economic development, and environmental dynamics.

Food sufficiency for rice commodities by district from 2016 to 2020 tends to be sufficient, although there are several districts that tend to be insufficient, namely Majene Regency and North Mamuju Regency. There is a change in food sufficiency from 2016 to 2020 , but this 
change leads to inequality. The projection results in 2025 and 2030 also show the same thing, namely Majene Regency and North Mamuju Regency are still in the insufficient category. Even in 2030 it is predicted that it will get worse with the addition of one other district that is included in the insufficient category, so that in general the province of West Sulawesi is predicted to be unable to meet food needs.

The implementation of regional policies about food management is necessary to improve food sufficiency, especially in North Mamuju and Majene Regency. The policies should attract investment in the agricultural sector, facilities and infrastructure development, technology utilization, capacity building of human resources in the agricultural sector, as well as the expansion of partnership networks, especially between farmers, government, and private sector. The development of sustainable agriculture and local wisdom is also expected to support the increase in food production and productivity so as to improve the quality and sufficiency of food.

\section{References}

1. Y. Y. Kurniawan, A. Daerobi, B. Sarosa, and Y. P. Pratama, J. Ilmu Ekon. Terap. 03, 1 (2018)

2. Pemerintah Republik Indonesia, (2012)

3. S. Apriani and Y. F. Baliwati, J. Gizi Dan Pangan 6, 200 (2011)

4. A. S. Somantri, P. Luna, I. Widi, and B. Waryanto, Inform. Pertan. 29, 95 (2020)

5. D. H. Azahari, Anal. Kebijak. Pertan. 6, 174 (2016)

6. R. Febriamansyah and S. Tarumun, J. Gizi Dan Pangan 10, 233 (2015)

7. B. Arifin, Risiko Dan Ketahanan Pangan Di Daerah Sentra Padi Kabupaten Pinrang, Universitas Gadjah Mada, 2012

8. Dinas Kesehatan Provinsi Sulawesi Barat, Rencana Aksi Daerah Pangan Dan Gizi Provinsi Sulawesi Barat Tahun 2015-2019 (2016)

9. Badan Pusat Statistik, Sulawesi Barat Dalam Angka 2015 (2015)

10. Badan Pusat Statistik, Provinsi Sulawesi Barat Dalam Angka 2021 (2021)

11. L. Abdullah, L. Wado, and K. X. Cenerawasih, J. Ketahanan Nas. 25, 178 (2019)

12. Presiden Republik Indonesia, (2002)

13. F. R. Ramdani and R. Harini, J. Bumi Indones. 14, 1 (2019)

14. J. M. Mawara, Pros. Semin. Nas. 2017 Fak. Pertan. UMJ 77 (2017)

15. Bappenas, Metadata Indikator Pilar Pembangunan Sosial Edisi II (2020)

16. N. U. Fauziyanti, M. A. F. Alfana, and R. F. Putri, IOP Conf. Ser. Earth Environ. Sci. 451, (2020)

17. F. T. Ahsani and D. Ardian, Semin. Nas. Off. Stat. 196 (2019)

18. M. Rachmat, Forum Penelit. Agro Ekon. 33, 1
(2015)

19. P. Alexander, M. D. A. Rounsevell, C. Dislich, J. R. Dodson, K. Engström, and D. Moran, Glob. Environ. Chang. 35, 138 (2015)

20. L. Muta and F. I. Rahmatullah, J. Bumi Indones. 6, 1 (2017)

21. P. Antonius, 2 (2021)

22. S. Mulia and D. Pasambe, Prospek Pengembangan Pertanian Di Propinsi Sulawesi Barat: Menyoroti Dinamika Pembangunan Pertanian Kawasan Timur Indonesia (Badan Penelitian dan Pengembangan Pertanian (Balitbangtan), Jakarta, 2008)

23. R. Harini, Indones. J. Geogr. 44, (2012)

24. Food and Agriculture Organization, The Future of Food and Agriculture: Trends and Challenges (Rome, 2014)

25. M. van Dijk, T. Morley, M. L. Rau, and Y. Saghai, Nat. Food 2, 494 (2021) 